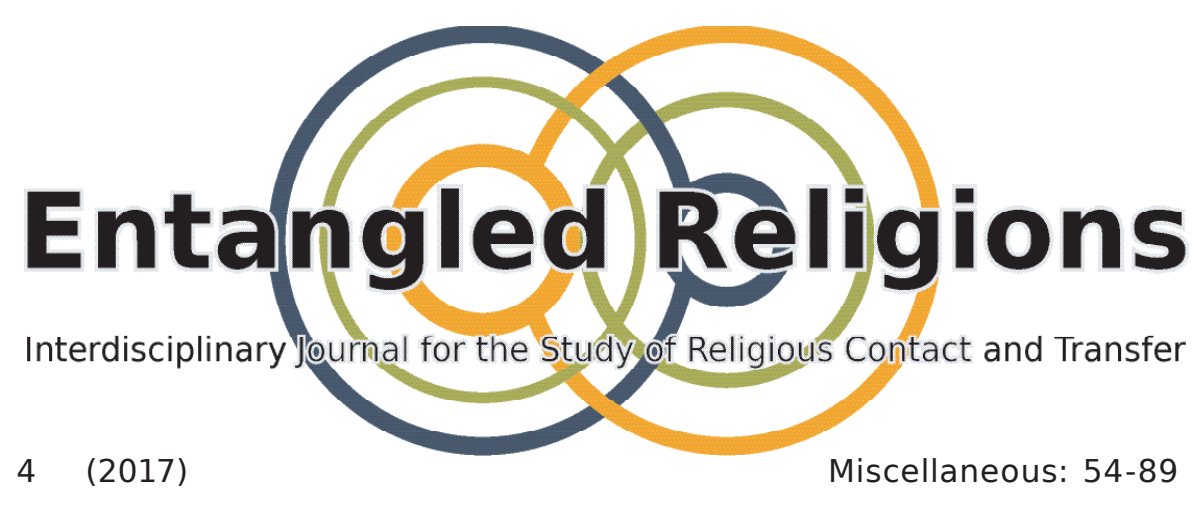

\title{
The Politics of Sufism and Hasidut in Medieval Egypt
}

\author{
BJÖRN BENTLAGE \\ Seminar for Arabic and Islamic Studies, Martin Luther \\ University Halle-Wittenberg, Germany
}

\section{GEROLD NECKER}

Seminar for Jewish Studies, Martin Luther University Halle-Wittenberg, Germany

\section{(C)}

This contribution to Entangled Religions is published under the Creative Commons Attribution-NonCommercial-NoDerivatives 4.0 International Public License (CC BY-NC-ND 4.0 International). The license can be accessed at http://creativecommons.org/licenses/ by-nc-nd/4.0/ or is available from Creative Commons, 559 Nathan Abbot Way, Stanford, California 94305, USA

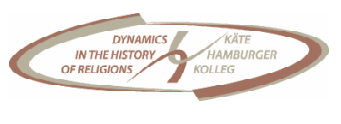

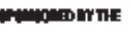




\title{
The Politics of Sufism and Hasidut in Medieval Egypt
}

\author{
BJÖRN BENTLAGE, GEROLD NECKER \\ Martin Luther University Halle-Wittenberg
}

KEY WORDS Piety, Sufism, Jewry, Copts, medieval Egypt, Ayyubids

\begin{abstract}
The present article is, firstly, a review of a recent publication by Elisha RussFishbane that will, secondly, seek to develop an entanglement perspective on piety in the Ayyubid age. Elisha Russ-Fishbane's book offers the first systematic presentation of the Jewish pietist movement in late twelfth- and early thirteenth-century Egypt. It is largely based on a selection of Genizah documents, the writings of the movement's pivotal figures, as well as a synthetic and critical discussion of the disparate remarks in previous publications. The present text will seek to summarize Russ-Fishbane's book, discuss it in relation to other pertinent literature, and suggest some thoughts on Jewish-Muslim relations, parallels to Jewish pietism in Germany, and the book's relevance for the perspective of entanglement.
\end{abstract}

\section{Introduction}

The newly founded series Oxford Studies in the Abrahamic Religions, edited by Guy G. Stroumsa and Adam J. Silverstein, has the potential to become a success story. The series started two years ago with a volume on The Making of Abrahamic Religions in Late Antiquity (Stroumsa), followed by Elisha Russ-Fishbane's Judaism, Sufism, and the Pietists of Medieval Egypt: A Study of Abraham Maimonides and His Times (2015). The title of the series addresses an academic field that emerged out of the increasing importance of comparative studies on Judaism, Christianity, and Islam. Without discussing the concept of "Abrahamic religions" here, it is obvious that the monographs to be included are meant to deal mainly 
with religious interactions. Nevertheless, it is still an open question how to weigh the comparative approach of religio-cultural crystallizations, on the one hand, and socio-historical contexts, on the other. The prominence of Ludwig Wittgenstein's "Familienähnlichkeit", which might be applied, rightly or wrongly, to a broader perspective, cannot gloss over the prevailing methodological uncertainty. This article will discuss the concept of entanglement, exemplified by Russ-Fishbane's study.

\section{Review}

Elisha Russ-Fishbane's study presents a concise and thorough analysis of Jewish piety in Ayyubid Egypt, sandwiched between a comprehensive introduction (40 pages), which tells the story of Abraham Maimonides, and the first part of the bibliography (Primary Sources) featuring main protagonists involved in the Jewish-Muslim relationship.

The study's objective is to describe the pietist movement - the author prefers the term hasidut instead of Jewish-Sufism - "from its inception in the second half of the twelfth century to its height in the first half of the thirteenth" (5). Russ-Fishbane rejects purely socio-economic explanations that view the pietist phenomenon primarily as a reaction to external crises, stressing that the movement must not be reduced to escapism: "The turn inward was at the same time a turn outward, in which mysticism and messianism constituted not an escape from society but a total regeneration of communal life" (8). In keeping with the title of the book, the author aims to focus the readers' attention on Abraham b. Moses Maimonides (11861237), delivering a sketch of Abraham's life (9-17), his dual position as Court Physician of the Ayyubid sultans and head (ra'is or nagid) of the Jews 
of Egypt (17-23), followed by an assessment of his importance in Jewish cultural history (23-25) and modern scholarship (25-43).

In contrast to his father Moses Maimonides (1138-1204), whose halakhic work became essential for the Jewish world and whose rationalist thought reverberated throughout the centuries, Abraham's works were, mainly and ironically due to the Arab language he chose for improving their dissemination, "only sporadically cited in theological and legal writings up to the sixteenth century, and became increasingly marginal to the intellectual and spiritual life of late medieval Jewry" (24). His chief importance derives from his leading role in the pietist movement. Egyptian Hasidism failed, however, to exert much influence beyond its immediate setting. At the end of the nineteenth century, when Western scholarship became aware of the Cairo Genizah containing thousands of fragments of religious and secular writings, especially from the period between the tenth and the thirteenth century, Abraham Maimonides was eventually rediscovered. The publication of his responsa by A. H. Freimann and S. D. Goitein in 1937, as well as the English translation of his major Compendium ("The High Ways to Perfection") by S. Rosenblatt in 1927/38, marked a crucial turning point.

For modern scholarship with its penchant for diachronic analysis, the Egyptian pietist movement figures as an especially interesting episode in Jewish cultural and religious history because it resembled Islamic Sufism in some respects, as was admitted by its proponents and opponents alike. Abraham Maimonides served as the prime example of a close affinity between Islam and Judaism in medieval Egypt, earning him a considerable boost of attention. ${ }^{1}$ Russ-Fishbane discusses a number of studies that focus on relations to Islam as a formative factor in the development of Judaism

1 See Russ-Fishbane's footnotes 90-94 on pages 95-96 for a list of editions and relevant studies. 
and therefore pay particular attention to Abraham and the pietists of Egypt (26-39). But in Russ-Fishbane's eyes, the idea of a Jewish-Muslim symbiosis, as favoured by S.D. Goitein and, in a revised form, by Steven Wasserstrom, does not consider the lack of reciprocity in the relations between Jews and Muslims: "As impressive as it is in the history of Jewish receptivity to Islamic civilization, Egyptian pietism connot be taken as a barometer of JewishMuslim symbiosis in general, or of mutual interfaith activity in particular" (35). Russ-Fishbane takes into account that Muslim scholars cannot be expected to have taken interest in internal Jewish affairs, and still less in Jewish Mysticism: “It was far more in keeping with the cultural and linguistic horizons of the religious minority to develop a meaningful, if dialectical, relationship with the spiritual traditions of the host community rather than vice versa" (ibid.). Nevertheless, it is difficult to cope with the complete spectrum of the multifarious Egyptian society ("host community" would be a misleading term) to which the Jewish residents belonged. The problem that Arab sources do not mention Jewish cultural or religious engagement - certainly not as we should like to have them - is no final evidence. Such an indifference may well be true for medieval Hebrew poetry (see, however, Norman Roth 1991), but if we look at the contemporaneous pietist movement in Ashkenaz (which will be addressed below), it is doubtful whether far-reaching conclusions can be drawn from the fact that no medieval Christian source recognizes an exclusive, almost sectarian Jewish group. ${ }^{2}$ Be that as it may, Russ-Fishbane continues by adducing Miriam Goldstein's examination of religious borders as a possible alternative to problematize inter-faith relations, briefly mentions Marshal Hodgson's

2 Even so, the actual existence of a pietist movement was questioned by Joseph Dan in order to describe, on the one hand, the literary character of Sefer Hasidim and, on the other, to differentiate the various schools of the Haside Ashkenaz in contrast to an alleged “movement", see Dan (1993, 2011). 
"Islamicate civilization," and then discusses two alternative approaches to Egyptian pietism: Nathan Hofer's (2015) application of post-colonial theory to Ayyubid and Mamluk Egypt that sees Jewish pietists as "subaltern Sufis," and the concept of "hybridity" espoused by Homi Bhabha and Jonathan Decter. But all of these approaches, in the author's view, come down to reducing the phenomenon in one way or another, whereas the goal of Russ-Fishbane's own study is to present a "nuanced examination of the pietist sources on their own terms, drawing as far as possible on their own definitions and perceptions" (39).

\section{"Social Foundations"}

Part 1 of the book describes the constitution of the pietist movement, regarding both its adherents and social context, and its foundational institutions and ideals. The first chapter sets out by sketching the background of Jewish cultural integration in much of the Islamic world, against which the pietist movement stands out for the apparent accomodation of Islamic ideas and practices in the field of religion, i.e. beyond the strictly cultural sphere. Russ-Fishbane places the beginnings of Sufi inspiration in the late twelfth century (46). He discusses the sources for and the difficulties in tracing the emergence of what was, judged in the light of Genizah documents, to become a tangible movement in Egypt in the early thirteenth century (47-52). The chapter continues with a discussion of how pietism related to the rationalist stance of Abraham's father, Maimonides, opting for an emphasis on elements of continuity instead of difference (53-55). The movement itself is then described as comprising members from all strata of life, and as clearly discernible from mainstream Jewry in Egypt, on which it nevertheless exerted some degree of influence (56-62). Several pages 
deal with the issue of family life, which allows for a series of interesting observations concerning the movement's self perception, frictions with the Jewish community at large, and internal distinctions among the pietists' regular adherents and elites (62-69). The remainder of the chapter treats the communal opposition against pietism in general and against the broader changes that pietist leaders like Abraham espoused. The charges levelled against them include those of outright heresy (71-75), the imitation of Islamic worship (huqqot ha-goyim) (76-85), and the vulgarization of what ought to be exclusive elite practices (85-88). The discussion of these charges is most instructive because it throws the movement's peculiarities into sharp relief. And Abraham's responses, especially regarding the alleged imitation of Sufis, are central for the question of Jewish-Muslim relations: In frank acknowledgment of the parallels to Sufi practice, Abraham claims that such Muslim practice had, in turn, be modelled on Jewish precedent, making it emblematic of the ideal faith and worship that Jewry should strive to return to after centuries of exile. His actual line of argument strains to adduce biblical and rabbinical proof for the existence of the seemingly Sufiinspired practices in Jewish history (76-85).

The second chapter follows up on two important points raised in chapter one, namely the importance of institutions and unique practices and beliefs for the constitution of a 'movement' (see 48-52), and the issue of Sufism as a model for Jewish pietist reforms (see 76-85). Russ-Fishbane describes the emergence of the pietist movement as 'organic,' starting with the pious inclinations of certain individuals all across the Islamicate Mediterranean, and culminating in "a complex system of mystical fellowship and discipleship that had all the trappings of an established movement" in thirteenth century Egypt (92). The institutions and practices that came to characterize that movement are identified as: spiritual guidance by a sheikh, fasting and nightly vigils, solitary prayer and private prayer groups (instead of the 
usually preferred communal worship), and meditation (including lengthy retreats in utter isolation), musical chants and melodic prayer, and a special attire that identified pietists in daily life and which was also used for symbolic initiations. For all of these 'ideals and institutions,' Russ-Fishbane discusses the issue of emergence - as far as that is discernible from the available sources - and presents Abraham's line of argument concerning the biblical and rabbinic precedent for the seemingly foreign innovations. The well-researched emergence of organized Sufi brotherhoods often serves as the backdrop for assessment of nascent Jewish pietism. In frequent reference to the pietists' own words, the author manages to flesh out the motivations behind these practices and the intended effects on the performing believer. The ideals and practices that constituted the pietist regimen thus emerge "as points of spiritual progression on the path toward mystical-prophetic insight" (122).

\section{"Prayer and the Synagogue"}

The very heart of Russ-Fishbane's study, as it turns out in Part 2, is an impressive presentation of Jewish devotional life in Egypt, which was guided by Abraham Maimonides into a new direction. The issue of deviant prayer gestures was taken seriously in these times, as Russ-Fishbane shows referring to a query on the legitimacy of prostration to the ground during the important statutory prayers. Together with other performances of prayer like night vigils, these gestures essentially characterize Egyptian pietism. Russ-Fishbane analyzes a central testimony written by a pietist in Arabic, which was published by Paul Fenton in 1993. In line with these specific pietistic requirements, Abraham Maimonides formulated his structural prayer reforms for the internal use of the movement. They 
are systematized in his ethical Compendium, as he himself states in the answer to the mentioned query. In addition, some Genizah documents are interpreted by Russ-Fishbane as indicating a controversy on these reforms within the Jewish Community (basing himself on the difference between liturgical and devotional reforms, as was elaborated mainly by Mordechai A. Friedman). The still towering authority of Abraham Maimonides' father matters, of course, in the context of the different aspects of the controversy; the limited extent of Abraham Maimonides' reforms in particular has been explained this way. But Russ-Fishbane surprises with a different argument. As nagid, Abraham provided the devotional reforms only for the pietist circle: "Not a single document from this period suggests that they were ever embraced in either of the main synagogues in Fustat" (143). Though this is an argumentum e silentio, it may intensify the profile of Abraham Maimonides as a pietist, which would have been incompatible with a powerful enforcement of rules regarding forms of devotion that could bewilder the non-pietist part of the community. At any rate, Russ-Fishbane explains the eschatological context of this "reluctant" approach, quoting e.g. the emphasis on the punishment for bad leaders in the Compendium, and he makes a good point on the relevant technical terms, which parallel those in Islamic jurisprudence (148). Interestingly, the (partly negative) perception of Jewish prayer gestures by the Muslim environment was also an issue for Abraham and his father, most notably the practice of prostration known as nefilat apayim (lit. falling on the face), which includes the turning of the head so as not to touch the ground, and for that reason was labeled by Muslims "the prostration of the Jews" (154f.).

The chapter on prayer reforms discusses one by one the following motifs: preparations, sitting (facing Jerusalem), standing, and, once more, bowing and prostration. Russ-Fishbane explains the emphasis on the latter again by referring to the Compendium: prayer postures follow a hierarchical 
order, which starts with sitting in a kneeling position, while standing is conceived as "more exalted" than sitting; next, bowing expresses greater humility than standing, but prostration is the highest level (176), and is called "the essence of worship" (183). In addition, the aspect of "concentration" is taken up again, and defined according to the anonymous pietist treatise (Fenton suggested Abraham he-Hasid, d. 1223, as author): “emptying one's mind and thoughts ... removing all distracting sounds and noxious sights that come from a preoccupation with doings of society and that lie hidden in the recesses of one's heart" (159). So there is a certain kind of meditation, which Russ-Fishbane calls "meditative cleansing," accompanying or introducing the prayer gestures. On the physical level, preparatory measures include also the Islamic custom of washing one's feet, which was already adapted by Abraham's father - as was noticed in the pietist treatise, too. The most exciting detail is revealed at the end of this chapter: pietist praying goes along with mystical experience, meaning "involuntary movements ... in a state of bewilderment" (181); the reference to manuals of Sufi masters like Najm al-Din al-Kubra (d. 1221) is quite convincing.

\section{"Prophecy and Messianism"}

The last part of the book starts with the observation that the Egyptian pietists did neither show interest in "theosophical expositions" like the kabbalistic circles nor in "divine gnosis" as featured in certain Islamic schools (189). The key to the mystical understanding is the linkage of "arrival" or "attainment" (wușūl) of prophecy and the perfection of the soul, both finding their goal in the conjunction with the world of the separate intellects. This may be called philosophic mysticism, but the terminology 
is familiar in Jewish esoteric Iore: Abraham Maimonides uses an Arabic equivalent (wușlah) for the Hebrew term devequt (193) - one could add that already Bahya ibn Paquda connected Sufi experience with the biblical command "to cling" to God" (cf. e.g. Deuteronomy 10:20, and see Lobel 2007, 222) -, meaning the act of adherence or attachment to the divine. This results in an experience of divine overflow, which is likened to brilliant light and heavenly music - which refers, as one might assume, to the angelic liturgy, a theme well-known since ancient times. A Sufi background (Suhrawardī al-Maqtūl) for the theme of divine illumination seems to supplement the strong influence of Maimonidean thought in the pietistic view of prophetic attainment. ${ }^{3}$ The most radical interpretation of RussFishbane is undoubtedly his understanding of Abraham Maimonides' pietist reform as messianic engagement by way of a "restoration of prophecy as a harbinger of the redemption" (222, emphasis Ruth-Fishbane). It is quite evident that the pietists considered themselves as "disciples of the prophets" (2 Kings 2:5), and actualization of the prophetic tradition was part of the self-design of the movement, which was based on the ideals of devotion, asceticism, and solitude, but also organized by spiritual leadership, which every student had to accept. A very helpful paragraph in this context is the explanation of Abraham Maimonides' commentary on the Sinai revelation, which figures as model and anticipation of the redemption to come (230f.). ${ }^{4}$ But it is questionable to what extent such an approach together with the practical forms of piety had been understood as the dynamic force of a

3 On the impact of Shihab al-Din al-Suhrawardi (1154-1191) see Eichner (2011).

4 However, the exegetical achievements of the pietists take a back seat in this study. It would have been interesting, for example, how the traditions related to God's holy names are dealt with by the pietists. It comes as no surprise that Abraham Maimonides noted in his commentary to the thirteen attributes of mercy (Exod 34:6f.) that Moses' prostration (Exod 34:8) actually preceded this revelation (Maimonides 1984, 98). 
"spiritual transformation that would usher in the messianic era" (233). It is left to speculation whether the messianic expectation of Maimonides, who revealed in his epistle to the Jewish community in Yemen a more personal view, gave rise to such an imminent expectation. On the other hand, it is quite comprehensible that his son Abraham held the family tradition on the end of days in high esteem (239). There is some reason to assume that the ambivalent relation to Islam, which was not only the ruling power and dominant culture but also an inspiration for the prophetic and devotional renewal of the pietists, intensified messianic tensions in Egypt; in the words of Russ-Fishbane: “In the messianic aspirations of Egyptian pietism, Islam had become both the outer crucible and inner conduit of a spiritual revolution in the heart of Israel" (243). If this was the case, then the Muslim environment probably was also related to the decline of the movement, which is still shrouded in some mystery.

\section{Conclusion}

Russ-Fishbane's Judaism, Sufism, and the Pietists of Medieval Egypt succeeds in what it set out to do: a presentation of the Jewish pietist movement in close correspondence with the sources, often citing directly from the material. To make sense of this material without superimposing theoretical expectations and to present a consistent history of the movement and its ascent is a considerable feat indeed. In addition, Russ-Fishbane refers to interpretations in the previous academic literature and manages to lay out a well-structured discussion on just 240 pages. However, the high level of scientific argumentation that characterizes this study partly represses the systematic presentation and intended synopsis. In fact, it reads, for the most part, as a deliberation of the status of research; the brevity 
of the main text is partly offset by the extensive footnotes that include condensed discussions and factual input while the narrative of the main text itself sticks closely to its line of argument and does not deviate much in the way of explaining preliminaries or context. Readers new to the topic of Jewish pietism will therefore quite often find themselves consulting reference works and introductory texts. Russ-Fishbane's book thus makes for rewarding but not always easy reading.

\section{Entanglement}

Even though his approach is decidedly different from the kind of entangled history perspective that this journal is devoted to, ${ }^{5}$ Russ-Fishbane's book and its topic are highly relevant for it as the following discussion will argue and seek to demonstrate. True to its title and stated objective, the study centers on Abraham Maimonides and the pietist movement. It does not say much about the political and cultural context of the Jewish community, ${ }^{6}$ which was far more complicated than a casual reader of the book would imagine: The Jewish Hasidim lived alongside Muslims and Oriental Christians on the former territory of a Shiite Caliphate that had succumbed to Kurdish champions of Sunni Islam, and in close proximity to Frankish Crusader states whose reinforcements had conquered Constantinople in the same year that Abraham's father died. Abraham himself was in communication with Jewish scholars and communities throughout the Middle East and Europe, and

5 Russ-Fishbane does not try to connect his findings to the concept of entanglement. The lexeme 'entangle' appears only once throughout the book and even then in the colloquial sense, see Russ-Fishbane, 4.

6 However, the title of Russ-Fishbane's (2009) unpublished doctoral thesis - which we could not consult for the present article - points in this direction. 
his family background connected him to the Jewish history and Islamicate heritage of Andalusia. Aware of this background, the opening pages of Russ-Fishbane's Judaism, Sufism, and the Pietists of Medieval Egypt - which include a polemical letter from Abraham to the Jews of Provence blaming them for their proximity to European Christians while remarking favorably on his Muslim neigbours and identifying in their practice and beliefs part of the biblical and prophetic ideals at the center of pietist endeavors - read like an intriguing prelude to a case study on religious entanglement. The following pages want to provide a sketch of what such an endeavor could look like.

First of all, it should be clear what is meant with 'entanglement'. For present purposes, it will be sufficient to refer to Margit Pernau's (2013) brief explanation how the concept of 'entangled history'- or 'connected histories', as similar approaches are preferrably termed in American academia emerged from comparative approaches and postcolonial theory. In short, the idea is to go beyond the comparison of different locales as autonomous entities and focus instead on the connections between them as a central factor that shaped developments, albeit possibly different ones, in both locales. Shifting the focus of historiographic attention to connectivity only makes sense, of course, in cases of strong and dense relations.

\section{Hypothesis}

What, then, are the dense connections and possible entanglements in the case of Abraham Maimonides and the Jewish pietists of medieval Egypt? Russ-Fishbane's analysis of the movement follows up on a long series of studies devoted to Muslim-Jewish relations and pays particular attention to its relation to Sufism, i.e. a certain strand of Islam. That would be a 
connection that is local as well as trans-communal and inter-faith. Here, one could add trans-regional connections to Jews in Europe and Jemen and the Indian Ocean world. The presence of Crusader states in the Levante was another important factor. Given the heterogeneity of the region hinted at above, a study that takes the ideas of entangled history seriously should obviously elaborate on the local context and question the quality and importance of the trans-regional connections.

Even more important, though, is to point out that an inquiry into interfaith relations under Ayyubid rule must not be restricted to Jews and Muslims. Even if the focus should remain on Egypt, excluding the religious diversity of Syria, Lebanon, and Palestine, it surely ought to include Egyptian Christians. Jews and Christians under Muslim rule shared the status of covenant or Dhimmi, and there is a wealth of related studies to draw from. Jørgen Nielsen (2010), for example, has written a thoughtful piece on how to conduct research on Dhimmis in medieval Egypt and Syria that takes into account the recent reorientation away from legal theory towards social history.

In addition to that and much closer to the venture point of Jewish Hasidim, Kurt Werthmuller's study of Coptic Identity and Ayyubid Politics in Egypt (2010) provides us with an interesting case study from roughly the same period and place. Werthmuller focuses on a period in the first half of the thirteenth century that brought with it great ecclesiastical disturbance in the Coptic community of Egypt, but which nevertheless bears evidence of a cultural and religious renaissance. Beginning in 1218, the Coptic patriarchy first remained vacant for 19 years and was then followed by a contentious eight-year reign of Cyril III ibn Laqlaq (d. 1243) in 1235. During the same time important works were written on Coptic canon law, theology, and poetry, and "a series of stunning wall paintings" were produced in chapels and monasteries, portraying "in uniquely vivid terms 
both the doctrine of the Coptic Jacobites and their contemporary frame of reference: the traditional pantheon of early Church figures is conspicuously absent, while figures highlighting the specifically Coptic tradition [...] are front and center" (Werthmuller 2010, 71). Despite internal and external crises, Werthmuller asserts, the Coptic church established itself as the predominant Christian entity in Egypt and moved to extend its jurisdiction beyond Egypt and exert more influence throughout the region.

How does this Coptic revival relate to the events depicted in RussFishbane's study? To answer that question, it may be helpful to go back to Margit Pernau's explanation of entangled history and its evolution from comparative historiography. Adducing the rough typology of approaches described there, what Russ-Fishbane's book really offers - apart from explaining the world of Jewish pietists on their own terms - is a regular comparison. The author uses Muslim Sufism as a folio to guide his investigation into the Hasidic movement. The case of Sufism in Egypt is especially interesting because its rise to a dominant strand of mainstream Islam and popular life also roughly coincided with the Ayyubid period, as Nathan Hofer (2015) has so neatly laid out. Russ-Fishbane drew on Hofer's dissertation to elucidate parallels and differences between Sufis and the Hasidim with regard to their respective institutions, fundamental ideas, and devotional practices. The existence of contacts and interactions between both groups is acknowledged but not deemed central; clear preference is given to the pietists' internal dynamics and motives, and the Sufic terminology is borrowed but not developed. The Coptic revival, now, shows no special resemblance to Sufism and its institutions, which is hence not a suitable folio for the analysis of the Coptic revival. The comparison begun by Russ-Fishbane can hence not simply be extended to include the Copts of Egypt. 
Taking a step back, however, a joint reading of the studies by RussFishbane, Hofer, and Werthmuller reveals the broad strokes of an emerging picture: they describe religious developments among Muslims, Copts, and Jews in the first half of the thirteenth century under Ayyubid rule. From a perspective of entangled history, it would seem worthwhile to hypothesize a connection between these developments. Following Pernau's suggestion, we will use the Muslim context as a baseline for the formulation of such a hypothesis. Sufism is too narrow and specific to serve us here; it was hardly the only religious development among Muslims in the region, though, and there is recent and rich literature to draw from in that regard. Josef Meri's (2002) study on The Cult of Saints among Muslims and Jews in Medieval Syria investigates the culture of mostly local pilgrimage and shrine visitation (ziyāra), which did not begin, but definitely flourished, during the Ayyubid period. And Daniella Talmon-Heller (2007) chooses places and practices of Muslim worship in order to look at the interactions of various social groups and strata in what really amounts to a well-written attempt to get a sense of religious daily life in the late twelfth and the first half of the early thirteenth century. Although both books have their focus on greater Syria and not on Egypt per se, they recurrently bring up examples from Egypt, too, and there is no compelling reason why their observations should not be assumed to also apply to the land of the Nile.

According to Talmon-Heller, the most important religious trends of the time were moderate Hanbalism and moderate Sufism, which developed from fringe movements to hallmarks of mainstream Islam and were seemingly less contradictory than one would nowadays assume. Together with flourishing popular practices like shrine visitations, public assemblies of exhortation, supererogatory prayer, and a robust upswing in the construction of religious buildings, these trends contributed to a general climate of religious revival in overt reaction and opposition to the Frankish 
Crusaders. Talmon-Heller speaks of "a pious age" $(2007,207)$ and has chosen the term "piety" for the title of her book: Islamic Piety in Medieval Syria: Mosques, Cemeteries and Sermons under the Zangids and Ayyūbids (1146-1260). "Piety" seems an appropriate and broad enough notion for a hypothesis about entanglement: The Ayyubid period in Egypt and Syria was an age of piety, in which large numbers of Muslims, Jews, and Christians engaged in novel or newly emphasized expressions of religiosity that were notably different from previous periods and probably instigated, in some way or another, by conflict with the Crusaders.

That is not to say, of course, that proponents of the Coptic renaissence, shrine visiting commoners, the Jewish nagid Abraham Maimonides, and Hanbali preachers were all the same. A central point of Russ-Fishbane's study, after all, is the idiosyncracy of even the seemingly Sufi-inspired Jewish pietism, and Christian developments are quite clearly set apart by monasticism and ecclesiastical hierarchy to begin with. But Sunni revivalism and the spread of Sufism, the re-emergence of the Coptic church, and Abraham Maimonides' Hasidim were nor unrelated either. How can such unclear relations be best described and explored?

\section{Terminology}

Acknowledging the conceptual difficulties of studying more than one context at a time, Pernau suggests a pragmatic approach that sets out from the terms and questions prevalent in studies of one context and then seeks, in the course of the inquiry, to open them up to accomodate developments in another context. In her own study, Pernau (2008) investigates entanglements between imperial Britain and colonized Northern India in the nineteenth century. She takes up the originally eurocentric notion of middle-class 
citizen (German "Bürger") and, through testing it against the experience of Muslim inhabitants of Delhi, develops a broader understanding of the term that allows her, metaphorically speaking, to picture a typical middle-class citizen with a turban as well as a hat, delivering the original title (Bürger mit Turban) of the study published in English translation in 2013. In pursuit of Pernau's suggestions regarding the case at hand, the notion of "piety" could serve as a root entry in a list of terms that are to be opened up and developed further.

What words and expressions were used to describe the qualities and characteristics that we now seek to grasp in a bundle? Thankfully, the existing literature contains some clues concerning "piety" as well as additional entries. Josef Meri (2002), for example, has argued for the existence of a shared vocabulary for prilgrimage and saint veneration (ziyāra) among arabophone Jews and Muslims. In much the same way, one should take stock of other terms and expressions that describe possibly related practices and behavior like special devotional practices, ascetic discipline, etc., and take note of the overlaps and differences in the usages of Jewish, Christian, and Muslim speakers of Arabic. This endeavor is somewhat complicated by the lopsidedness of the available source materials. Meri's assessment of a shared vocabulary, for instance, excludes Christians because they apparently did not contribute to the otherwise blossoming genre of Arabic pilgrimage guides at that time, although their presence at shrines and participation in some rites is well attested for (Meri 2002, 4). Werthmuller (2010), on the other hand, finishes his book with an appeal to invest more energy to unearth and gain access to Christian Arabic sources, especially from monasteries in Egypt.

In addition to that - and partly drawing on Nielsen's (2010) thoughts about Dhimmis, but also inspired by the other books adduced here we want to suggest a few lines of inquiry through which the assumed 
entanglement could be tested and explored. They include the broad themes of agency, trans-regional connections, and religious boundaries, which all may be looked at with regard to religious communities as a whole (i.e. Copts and Jews), to individuals or specific groups, to the Ayyubid state and institutional structures, and to dynamics of change.

\section{Agency}

Our discussion of agency will start with the state. What agency did the Ayyubid government have in matters of religion and piety? To answer that question, it is important to say something about the character of the Ayyubid polity and bear in mind that this was not the time for territorial states with clearly delineated borders and unquestionable state hegemony. Instead, we should think of areas under stricter or looser control, areas under external threat, and so on. Saladin's rise to power and the kind of rule over Egypt and Syria that he and his successors exercized may be better understood as a project to establish authority and control. Considering the tumultous struggles of the late Fatimid era, from which Saladin and his Kurdish forces emerged, the repeated back and forth with the Crusaders, and the constant threat of internal rivals, really any kind of political stability seems noteworthy. This is illustrated inter alia in that Saladin sentenced al-Suhrawardi - who is mentioned in Russ-Fishbane's study - to death, according to Nicolai Sinai because of the philosopher's commitment to Shiite terminology or concepts revealing Ismaili sympathies and, above all, the prophetic claim of his philosophy of illumination (Sinai 2011, 23638). At a time in which, for example, the Ismaili followers of Hasan Sabbah controlled the mountain fortress Alamūt in Northern Irak, Saladin would 
not needlessly jeopardize the support of his religious authorities in Aleppo, where al-Suhrawardi had a privileged position.

Yet Saladin and the Ayyubids did more than merely hold on to territory. As Stephen Humphreys (1977) remarks, "Saladin's legacy to his heirs [...] was a functioning political system [... that] gave his immediate successors a framework [...] within which to define their own policies and goals" (15). Mixing elements of collective family rule with an ideal of sultanic supremacy, it took the form of a confederation of principalities held together by family loyalty to the Sultan. Recognizing that neither Saladin nor his heirs commanded overwhelming military force or strong institutions, Humphreys turns to other factors to explain the relative success of the Ayyubid project. He considers the "ethical character" of the state to be instrumental, namely the "sense of mission" to revive Sunni Islam and wage jihad against the Crusaders (20). The way that the essentially military dynasty of the Ayyubid actually promoted this was through princely patronage of religious men and institutions.

Humphreys' study is a political one and its focus lies on the actions and possibilities of Ayyubid princes and sultans. He analyzes the Ayyubid practice of patronage for religious institutions as an instrument for the crucial alignment of elites that formed the backbone of the Ayyubid political system. Sponsoring Sunni scholars and founding mosques and shrines may have been in line with a given ruler's personal outlook, but it also dovetailed with the jihadi-aspect of the counter-crusade. From that vantage point, which looks at religious developments primarily through the lens of government action, such as patronage of certain currents and crackdowns on others, the Sunni variant of piety appears to have been state-driven. Nathan Hofer's study reinforces that point. His examination of Ayyubid patronage demonstrates that Saladin and his successors did more than merely coopt an elite. The founding and funding of major Sufi hospices like 
the Sa'īd al-Su'ādā' in Cairo (1173) were conscious policies to change the symbolic makeup of the city and shape religious views within the realm. Saladin gave instructions to house and feed about 300 Sufis, giving clear preference to sharia-minded ascetics and mystics from the East. The duties and actions of these state-funded Sufis included decidedly public functions: They "performed public rituals every evening, they paraded through the streets of Cairo every Friday", blessing the sultan, "and they frequented the city's many madrasas, mosques and teaching circles," (90, see also 79-80). Their presence and public actions were clearly fit to bolster the legitimacy of Ayyubid rule. Similar hospices as well as madrasas and numerous mosques and shrines were founded by Ayyubid princes in various towns and cities across Egypt and Syria.

The agency of the Ayyubid regime must not be overstated, though. Even in Egypt, where bureaucracy was more centralized than in greater Syria, state institutions remained rather weak and stood opposite religious communities and urban societies, who retained a certain degree of autonomy. The situation of Jews and Muslims was partly determined by their legal status as "covenants" or Dhimmis (also ahl al-kitāb or "people of the book"), discriminating them while also guaranteeing some degree of communal self government. Ayyubid rulers certainly had a role to play in the selection and designation of the heads of the non-Muslim communities. Werthmuller (2010) describes the intra-communal politics of the Coptic church and some of the customs concerning the selection of the patriarch. Interestingly for our current purposes, his account of Cyril III ibn Laqlaq's patriarchy gives clues about the entanglement of the Coptic community with the Ayyubid state, about the extent and limits of each side's agency in matters of joint concern. Regarding the matter of the patriarchy itself, for instance, it apparently took a decision by the sultan to install a patriarch, as becomes clear from Ibn Laqlaq's first initiative to claim the see in 1218, for 
which he - an otherwise unknown monk - relied on personal connections to the state bureaucracy. Yet it also becomes clear that sultanic support was not enough: the resistance of Coptic bishops put an end to Ibn Laqlaq's first attempt and resulted in a 19-year vacancy of the office. And then there is the matter of ecclesiastical authority, in which, as we learn from Werthmuller's account of Ibn Laqlaq's patriarchy, the Ayyubid state sometimes had a hand, too. Because on the one hand, Ibn Laqlaq - once he did attain the patriarchy, thanks to his connections to the throne - sought to re-establish and extend patriarchal authority and jurisdiction. But on the other hand, the "re-establishment of Church law" was overseen by a canonical council that included Muslim bureaucrats (Werthmuller 2010, 69-71). It seems that Ibn Laqlaq as patriarch, as well as the opposition to him among the Copts of Egypt, developed relations to the Ayyubid state in order to gain support in internal contestations. These entanglements may not be surprising but surely demand further inquiries, especially if we take into account that the Coptic church claimed authority beyond Ayyubid territory. Ibn Laqlaq, for example, asserted his jurisdiction over some Frankish communities in Syria and Palestine and entertained epistolary contact with the ruler of Ethiopia. Did the religious policy of the Ayyubid state ever extend to their Dhimmi subjects in ways that sought to further through them the Ayyubid quest for strength and control?

Russ-Fishbane narrates Abraham Maimonides' laments about the duties and the necessary proximity to the ruler that went along with his function of representing and, in a sense, governing the Jews of Egypt. Nevertheless, there was considerably less interference of the Ayyubid government in Dhimmi-affairs than Islamic matters, which were part of the state's religious policies, and the Jewish and Coptic communities could exercise internal jurisdiction and maintain semi-diplomatic contacts to communities and rulers beyond the Ayyubid domains. With regard to the communal 
structure of the Muslim populace, however, the situation is much less clear. With the exception of the Hanbalis, who apparently built mosques of their own and formed distinct dommunities, it remains uncertain if Muslims in general were an "amorphous mass" (Nielsen 2010, 9).

According to Jørgen Nielsen, recent scholarship on Dhimmis has shifted considerably and now, instead of devoting itself to those aspects that were indeed circumscribed by legal doctrine and government policies, tends to ask about the "participation" of Christians and Jews in the "more complex terms of the subject populations in general" (Nielsen 2010, 6f.). And in this regard, the interplay of "commoners" ('āmma, 'awwām), religious elites ('ulamā'), and military government may best be understood from a synthesis of the literature. Humphreys (1977) identifies the primary political problem of the time to be "the satisfaction of the interests and ambitions of a tiny elite," and specifically "not the mobilization of mass opinion, however desirable that may have seemed in itself" (20) from that perspective. Hofer's general argument is not primarily about the role of military rulers, because in addition to the mentioned part about state-sponsored Sufism, his study also includes chapters on "unruly Sufism," that is to say, forms of Sufism that ran counter to the regime's interests. He also rejects the notion that a spiritual longing on the side of the populace should have been the prime factor in the spread of Sufism. Rather, Hofer's main point is to draw attention to the agency of Sufis themselves, who came to Egypt, engaged with people, performed in certain ways, organized, communicated, and thus produced distinct Sufi cultures that they brought to the populace instead of the people seeking it out. The popularization of Sufism in Ayyubid Egypt, according to Hofer, involved "the interplay of multiple strata of society" (13), but was really driven by the actions of Sufis, who may well be thought of as part of the religious elite, their use of specific concepts and practices going back to a formative period in Baghdad, and their interactions with 
the state. In a similar vein, Talmon-Heller is also interested in the "complex relationships between rulers, scholars, and the wider public" $(2007,3)$, but her study puts the emphasis on the agency of commoners, who, for example, took part and contributed to the establishment, refurbishment, and upkeep of shrines and mosques. Among the illustrative evidence is the persistence of popular forms of devotion and their entry into the liturgical calendar in spite of scholarly disapproval and occasional princely decrees. The fact that topoi about the re-discovery of graves and the founding of new shrines, in addition to an individual receiving some sort of sign, include an audience of people ready to believe and spring into action also speaks to the agency of commoners. Another aspect that relates to agency has to do with religion proper. Werthmuller's account of Ibn Laqlaq and his times is based on the works of Muslim historiographs and the Coptic History of the Patriarchs. The History's narrative repeatedly asserts divine agency with regard to decisions by the Ayyubid rulers that benefit the Coptic community or at least cease to inflict upon them.

Regardless of emphasis, the different takes are not mutually exclusive but rather complement each other and invite further synthesis. The central point here seems to be the involvement of several sides in the expression and creation of (Muslim) piety in Ayyubid times. Furthermore, the piety that was created through these interactions was essentially social and played a pivotal role in creating cohesion and identity among the communities, social groups, and inhabitants of the re-conquered and usurped realm. When we acknowledge that, as Talmon-Heller (2007) argues, the communication of the religious "class" of preachers, Sufis, imams, and other ulama functioned as one of the few medieval equivalents of mass media, and if we accept that interactions between rulers, religious elites, and commoners primarily happened on religious occasions, in religious venues, and used a religious 
vocabulary, piety appears to be not so much the product but the very mode of their engagement with each other.

\section{Inter-regional connections}

Inter-regional connections are another theme that an entanglement approach to piety in the Ayyubid period ought to explore. It is a difficult aspect, for sure, because communities and social groups may have many different ties that will soon exhaust any given set of expertise. Yet even though it will not be possible to follow up on all connections, the links and relations between the Ayyubid realm and other regions need to at least be considered. The popularization of Sufism, for example, has to do with the transfer of institutional and organizational patterns as well as migration from the East. Humphreys traces the patronage and religious policies of the Ayyubids back to the example of the Seljuk empire in Iran and Iraq, which Saladin had experienced second-hand during his service for the Zangid commanders; this is a connection of military elites (Humphreys 1977, 7173). Hofer (2015), on the other hand, describes a transmission through religious elites as he calls attention to the surprisingly local roots of some of Sufism's main constitutional ideas like discipleship in Baghdad. And when Saladin established the large Sufi hospice Sa'īd al-Su'adā' in Cairo, lodging was granted to hundreds of Sufis with specific preference for sharia-minded ascetics and mystics from the East, which basically amounts to a statesponsored migration of religious elites which suited the Ayyubid project of Sunni revival. Talmon-Heller also stresses the importance of "itinerant and emigrant teachers and students," adding the flow of Muslim migrants from al-Andalus and the Arabic West to the list of trans-regional connections to be considered. And specifically concerning the culture of shrine visitations 
in Ayyubid times, Talmon-Heller mentions discussions about the possible influence of the Crusaders' presence for the intensification of Muslim shrine cults $(2007,206)$.

Jews and Christians tied into different networks. The Maimonides family originally hailed from Spain and Abraham and his father were in communication with co-religionists in the Middle East and Europe. We also know of trade networks reaching far into the Indian Ocean (Gil 2004; Stillman 2014). The connection to European Jews - conducted in Hebrew and not in Arabic - may have been of more importance for the development of the pietist movement in Egypt than Russ-Fishbane's analysis lets on. RussFishbane draws a contrast between the prayer gestures that characterize Egyptian pietism and the hallmark practices of German pietiests (hasidei ashkenaz) in the same period, who relied heavily on "numerological or theosophical speculation;" no trace of such methods and ideas are to be found in Egyptian pietism (136). Unfortunately, this was Russ-Fishbane's last word on the comparison with hasidut in medieval Germany, though it could have been helpful to ask the question the other way around, and, in consequence, realize that innovative prayer gestures also play a significant role among German pietists (Marcus 1995); in their case, the mystical significance of the actual practice corresponds with a new understanding of Hekhalot-literature. New concepts, established from the thirteenth century onwards, like shutting or closing one's eyes, are also discussed by Spanish kabbalists, who referred to the German pietists (Mottolese 2016). The typical act of 'concentration' mentioned in the query seems to be a common denominator of Egyptian and Ashkenazi pietism. Yet another rendering of a mystical experience that went along with pietist praying, which recalls the Sufi inspiration of Najm al-Din al-Kubra (see above), runs parallel to the mystical literature in medieval Europe. The whole phenomenon resembles descriptions of direct experience of the Holy Spirit in visions and ecstatic 
prayer. Moshe Idel (1988) introduced his analysis of Abraham Abulafia's prophetic Kabbalah with examples from the German pietists, like the Sefer ha-Hayyim (written in Northern France at the end of the twelfth century), which mentions tremor, arousal, and a kind of spirit-elevation as a result of the constant repetition of holy names (16). And a last example: the final quotation from Abraham's Compendium in Russ-Fishbane's chapter on Prayer Reforms, Psalm 84:3 ("my heart and my flesh sing out to the living God"), ${ }^{7}$ which is offered by Russ-Fishbane as the pivotal idea of the intimate relationship between prayer and "the forces of the body" (183f.), appears also in Judah he-Hasid's Sefer Hasidim in an exemplum of a Hasid, who was in the habit of blessing each and every limb in order that they may serve well their creator. ${ }^{8}$

The Copts of Egypt, on the other hand, had less connections to Western Europe. Werthmuller (2010) points out that Ibn Laqlaq maintained close contact to Franks in the Levante and to other monophysite churches in the Middle East. The fact that the part of the Ayyubid empire that was most vulnerable to conquest by Crusaders during the thirteenth century was the Nile Delta made things complicated for sure.

\section{Boundaries}

One way to talk about the presence of and the interactions and distinctions between Muslims, Jews, and Christians in Ayyubid Egypt and Syria is through the consideration of religious 'boundaries'. Certainly, this notion, like any

7 For the kabbalistic context of Psalm 84:3 referring to the daily prayer (Amidah) see Sefer ha-Zohar 1:209b.

8 Sefer Hasidim §2 [Parma], https://etc.princeton.edu/sefer_hasidim, accessed February 17, 2017). 
metaphorical shorthand, carries with it some problematic implications that one needs to be aware of - namely clear-cut delineation: you either are Muslim, Jew, monophysite Christian, etc., or you are not - so that an unreflected use of the term runs the risk of neglecting all kinds of relations that are not as definitive. But, thankfully, these and other concerns have already been addressed and accommodated for in the technical understanding of the term. ${ }^{9}$ For our present purposes, 'boundaries' will be useful for the discussion and partial integration of observations concerning interfaith relations in the literature.

Nielsen (2010), for example, notes the general pattern that religious boundaries tend to be somewhat porous and permable at the level of popular culture, but are constantly re-imposed and emphasized by "religious professionals of all communities," whose authority was generally supported and reinforced by the state (9). Although public life in larger towns was certainly dominated by Islam and some non-Muslim communities stayed in separate villages and quarters, mixed areas of living were also common and we can safely assume a good degree of everyday encounters. In addition to commercial transactions and some legal affairs, which frequently brought non-Muslims to appear before Islamic courts, there was some degree of interaction in the spheres of religion and culture, too. For Egypt, we know of certain feasts, some of them with Christian origins, in which people from all faiths participated (Werthmuller 2010, 33), and larger and spectacular Islamic events like exhortations and Sufi processions also drew attendees and watchers from other creeds (Talmon-Heller 2007, 129; Hofer 2015, 90-93). Shrine cults and the veneration of saints seem to have been particularly conducive to interfaith contacts in religious activities, and especially the prophets of the Abrahamic tradition were sought out by 
visitors of different religious backgrounds. It must be stressed, though, that the shared aspects of the culture of visiting the dead - attested in medieval Judaism in the tenth century already (cf. the polemics of the Karaite Sahl ben Masliah ha-Kohen [910-990] on the "idolatrous" Jewish custom to visit graves and pleading the saints for help; Meri 2002, 220-222) - has been researched mostly with regard to Jews and Muslims in medieval Egypt and Syria whereas we know less about the participation of Christians in shrine cults (Meri 2002, 4; Talmon-Heller 2007, 199-202). Notwithstanding doctrinal differences in Islam and Judaism concerning death and the dead, Talmon-Heller sees the ziyāra culture as an outflow of an "overall religious climate" in the Ayyubid period: "visits to holy sites, their routine upkeep, and the establishment of new sanctuaries were fine outlets of piety in a "pious age'," (2007, 207). In addition to these special occasions and practices, there are indications that piety and ascetic discipline in general had a transcending appeal, as illustrated in Werthmuller's account of a certain monk's authority and respect for him beyond the circle of his coreligionists (2010, 109).

These instances of involvement are countered, according to Nielsen (2010), by religious elites and their reassertions of boundaries and difference. Adherence to norms was taken seriously, even with regard to largely formalistic prescriptions like prayer gestures. And the religious literature is replete with efforts to balance definitions of and charges with aberration, apostasy, conversion, and reversion. Nielsen likens the social function of religious elites - although in a slightly different context - to that of a magnet: "The [normative] expectations [...] were a constant measure against which realities were tested, in the breach as much as in the observance: they functioned like a magnet counteracting the centrifugal forces of local particularities whatever their natures" (2010, 7). This general dialectic should, however, not be understood as a strict 
dichotomy of potentially syncretic popular culture and religious orthodoxy, as Talmon-Heller has convincingly demonstrated by highlighting the orthodox qualification of most popular preachers and Sufis, on the one side, and the surprisingly popular stances and actions of the supposedly orthodox, on the other.

Boundaries are drawn from the inside just as they can be imposed from the outside. And because of the latter, the status of non-Muslim communities is often judged according to the balance between episodes of aggression against them and periods of more or less amicable participation. Religious boundaries mark, at times, the front line against the enemy, and at other times function as an interface for engagement in a joint environment. The question of a shared culture or shared cultures is of obvious significance here and has been raised in a number of studies, especially with regard to Jewish-Muslim relations. Various takes on this issue - ranging from the assumption of a "symbiosis" to approaches rooted in postcolonial theory and subaltern studies - are discussed by Russ-Fishbane (26-39), Nathan Hofer (2015, 252-54), Nielsen (2010), and Werthmuller (2010, 62-63, 1428), while Meri's entire study may be taken as an attempt to expound on Goitein's proposition of a shared culture (2002, e.g. 6, 281-84).

The endeavor to develop and test an entanglement perspective on piety would probably benefit from a better integration of the Christian contribution to the shared culture(s) of Ayyubid times. The importance of Coptic scribes and bureaucrats has been known for a long time, whereas the question of Christian participation in terms of culture and religion received less attention. Werthmuller's (2010) approach is a laudable step in that direction, as it draws from the technical vocabulary developed with regard to Jewish-Muslim relations. Surely more can be learned from the available sources and from those yet to be found if efforts to investigate Christian Arabic manuscripts were to be intensified. And even though 
textual sources are often silent on the most salient points with regard to religious boundaries and interaction, their restrictions can be alleviated somewhat by the approaches already developed in the existing literature. Considering Nielsen's (2010) observation about the cohesive function of religious elites, for example, and Talmon-Heller's (2007) interest in places of worship as the spaces of interaction across different strata, it seems entirely possible to further our understanding of communal integrity and borders through more comparisons of religious locales like monasteries, Sufi hospices, synagogues, mosques, etc. Russ-Fishbane's differentiation between the pietist movement proper, which often assembled in private homes, and general pious trends observable in synagogues, is an important contribution in that regard.

\section{Dynamics of change}

When talking about piety in the Ayyubid age, it is important to consider dynamics of change, both with respect to sudden crises and to long term developments. Werthmuller provides us with a useful overview of how Christians and other non-Muslims fared under Fatimid, Ayyubid, and Mamluk rule, going beyond the question of legal status to elicit broad and significant dynamics. Generally speaking, non-Muslims experienced harmful and hostile episodes in all three periods, but these were exceptions in the case of the Ayyubids, whose political framework still gave considerable room to non-Muslim communities and individuals, while the Mamluk era, following the cataclysmic invasion of much of the Middle East by Mongol armies, brought about a different climate that led to a marked deterioration of Dhimmi communities in Egypt and Syria. The Ayyubid era itself, as noted by Humphreys (1977), upended a long-lasting regional balance of power 
establishing Egyptian dominance over Syrian lands for the next two-anda-half centuries. The Ayyubid project of counter-crusade and consolidation ushered in a transition to more unified forms of state rule under their successors. And religion had a lot to do with that because the formation of cohesion and stately authority relied on a new constellation of rulers, religious elites, and the populace, which manifested itself, for example, in the setup of regal and religious architecture in cities and their layout. The possibly entangled trends of piety, i.e. the marginally contentious but mainly consensual desire to identify pious behaviour, to live up to and partake in it, may likewise be seen as one of the ways through which this re-configuration of communities, society, and authority came about in Ayyubid times.

\section{Epilogue}

It remains to be seen whether the hypothesis of entanglement bears out or not. But the existence of all kinds of interactions and connections between various actors, locales, and contexts is a matter of fact. And since the political frame alone offers no idea about the intrinsic factors and dynamics of the environment in question, whereas within this framework, the shimmering and sometimes blending colours of religious attitudes do, the focus on individual movements resulting in detailed, often highly specialized information should be followed with increased attention to the connecting lines. Obviously, such a focus demands different research strategies. Visual arts may intuitively invite the sort of linking looked for by entanglement: the jacket image of Russ-Fishbane's book shows a Persian miniature from the end of the sixteenth century, "a young man visiting a dervish." In any event, searching for entanglement in the case of Hasidim, 
Sufis, monks, ascetics, and Hanbalis must be guided by the threads of piety during the Ayyubid era, no matter where and whether they converge. But be that as it may, the substantive examination of the sources presented by Russ-Fishbane makes an important contribution to the state of the art. His study on Abraham Maimonides and the Hasidim sheds light on an exciting episode in the history of Middle Eastern Jewry and of Egypt, and is also fit to support a more connected history of piety in the Ayyubid age.

\section{Reference List}

Dan, Joseph. 1993. “Ashkenazi Hasidism, 1941-1991: Was There Really a Hasidic Movement in Medieval Germany?" In Gershom Scholem's Major trends in Jewish Mysticism: 50 Years After, edited by Peter Schäfer and Joseph Dan, Tübingen, 87-101.

Dan, Joseph, 2011. History of Jewish Mysticism and Esotericism [Hebr.], vol. 5, Jerusalem: The Zalman Shazar Center for Jewish History, 68-74.

Eichner, Heidrun. 2011. “'Knowledge by Presence', Apperception and the Mind-Body Relationship: Fakhr al-Dīn al-Rāzī and al-Suhrawardī as Representatives and Precursors of a 13th century Discussion." In In the Age of Averroes, edited by Peter Adamson. London: Warburg Institute, 117-140

Gil, Moshe. 2004. Jews in Islamic Countries in the Middle Ages. Translated by D. Strassler. Leiden: Brill.

Hofer, Nathan. 2015. The Popularisation of Sufism in Ayyubid and Mamluk Egypt, 1173 - 1325. Edinburgh studies in classical Islamic history and culture. Edinburgh: Edinburgh Univ. Press. 
Humphreys, R Stephen. 1977. From Saladin to the Mongols: The Ayyubids of Damascus, 1193 - 1260. Albany, NY: State Univ. of New York Press.

Idel, Moshe. 1988. The Mystical Experience in Abulafia. State University of New York Press.

Lobel, Diane. 2007. A Sufi-Jewish Dialogue: Philosophy and Mysticism in Bahya ibn Paquda's Duties of the Heart. Philadelphia: University of Pennsylvania Press.

Maimonides, Abraham. 1984. Perush Rabbenu Avraham ben ha-Rambam $z^{\prime \prime I}$ 'al Bereshit u-Shemot. Edited by Ephraim J. Wiesenberg, Jerusalem.

Marcus, Ivan. 1995. "Prayer gestures in German Ḥasidism.“ In Mysticism, Magic and Kabbalah in Ashkenazi Judaism, edited by Karl Erich Grözinger and Joseph Dan. Frankfurt a.M., 44-59.

Meri, Josef W. 2002. The Cult of Saints Among Muslims and Jews in Medieval Syria. Oxford oriental monographs. Oxford: Oxford University Press.

Mottolese, Mauricio. 2016. Bodily Rituals in Jewish Mysticism: The Intensification of Cultic Hand Gestures by Medieval Kabbalists. Los Angeles: Cherub Press.

Nielsen, Jørgen S. 2010. "The Participation of Christians and Jews in the Ayyubid and Mamluk State: A Historiographical Reflection." In Towards a Cultural History of the Mamluk Era. Würzburg: ErgonVerlag.

Pernau, Margrit. 2013. Ashraf into Middle Class: Muslims in NineteenthCentury Delhi. Oxford: Oxford University Press.

Pernau, Margrit. 2008. Bürger Mit Turban: Muslime in Delhi Im 19. Jahrhundert. Bürgertum. Göttingen: Vandenhoeck \& Ruprecht. 
Roth, Norman. 1991. "Muslim Knowledge of the Hebrew Bible and Jewish Traditions in the Middle Ages." Maghreb Review 16: 74-83

Russ-Fishbane, Elisha. 2015. Judaism, Sufism, and the Pietists of Medieval Egypt: A Study of Abraham Maimonides and His Times. Oxford Studies in the Abrahamic Religions. Oxford/New York: Oxford University Press.

Russ-Fishbane, Elisha. 2009. “Between Politics and Piety: Abraham Maimonides and his Times," Ph. Diss., Harvard University.

Sinai, Nicolai. 2011. Shihāb al-Dīn al-Suhrawardī: Philosophie der Erleuchtung Hikmat al-Ishrāq. Berlin: Verlag der Weltreligionen. Stillman, Norbert A. 2014. “How Mediterranean was Goitein's Mediterranean Society?" In Jews, Christians and Muslims in Medieval and Early Modern Times: A Festschrift in Honor of Mark R. Cohen, edited by Arnold E. Franklin et al. Leiden: Brill: 29-39. Talmon-Heller, Daniella. 2007. Islamic Piety in Medieval Syria. Jerusalem Studies in Religion and Culture. Leiden/Boston: Brill.

Werthmuller, Kurt J. 2010. Coptic Identity and Ayyubid Politics in Egypt, 1218-1250. American University in Cairo Press. 